\title{
SUCCESS STRATEGIES IN ISLAMIC MARKETING MIX
}

\author{
Johari Bin Abdullah* \\ Universiti Teknologi MARA \\ Jamil Haji Hamali \\ Universiti Teknologi MARA \\ Firdaus Abdullah \\ Universiti Teknologi MARA
}

\begin{abstract}
Islamic marketing (IM) is gaining momentum in the development of marketing knowledge and its practical implication to business and customer is undeniably significant. In fact, it has been growing rapidly in the past years and has grabbed the attention of both academics and practitioners of marketing. Nevertheless, this area still remains understudied with limited empirical evidence, particularly on marketing mix decisions or four Ps (product, price, promotion and place) in line with Islamic principles. Therefore, this paper attempts to identify critical factors in conducting Islamic marketing mix activities and their relative importance. Using combination of both qualitative and quantitative research method, this paper proposed a set of 23-item instrument that measures Islamic marketing mix which has been empirically tested for its unidimensionality, reliability and validity through factorial analyses. Findings suggest that Muslim customers consider five critical factors that must be emphasized by businesses in conducting their marketing mix. In their order of importance using multiple regression analysis, the factors are 'Conformity', 'Character', 'Commitment', 'Conscience' and 'Customer Centrism'. Therefore, it is proposed that businesses can adopt the strategies in engaging with Muslim customers through their marketing mix activities by consistently conforming to Syariah, exhibiting distinctive characteristics, instilling assurance, embedding morality and conscience and lastly embracing a 'customer oriented' approach.
\end{abstract}

Keywords: Islamic Marketing; Marketing Mix; Factorial Analyses.

\section{INTRODUCTION}

Islamic marketing (IM) is a relatively new development in marketing thought and the term IM has not been addressed satisfactorily in the literature. In fact, despite the prominence of Islam, there has been little literature on Islamic marketing (Temporal, 2011; Alserhan, 2010). Based on the works of Muqorobin (2004), out of 4565 publication on Islamic economics

2 Corresponding author: Johari Bin Abdullah, Faculty of Business Management, Universiti Teknologi MARA, Sarawak, Jalan Meranek, 94300 Kota Samarahan, Sarawak, Malaysia. Phone No. +60109668869,+6082677674. Email: johariabdullah@sarawak. uitm.edu.my 
ranging from $1994-2005$, only $0.61 \%$ was securitized on marketing. Whereas banking and finance theory were $20.75 \%$ and $19.28 \%$ respectively. Based on database search in 2012 , there were only 155 literatures that focus on marketing exists in the Islamic economics (IIUM, 2012). Nevertheless, major turnaround is on the way as the new millennium has shown rapid development of businesses strategy within an Islamic framework, particularly in Islamic marketing. As claimed by Sandicki (2011) the discovery of Muslims as one of crucial prospects for business is rapidly changing the above situation. Since 2010 there has been a growing number of publications and research on Islamic marketing, branding and Muslim customers.

Such a momentum is triggered by sizeable Muslim populations that present a great potential of new untapped consumer markets in the global business arena. As estimated by Pew Research Centres (2009), there were 1.57 billion Muslims in 2009, representing 23\% of the world population of 6.8 Billion. By 2030, the Muslim population is estimated to have grown from 1.57 billion to 2.2 billion, increasing by about $35 \%$ in the next 20 years. This enormous number of Muslim people is expected to follow the Islamic way of life that covers every sphere of daily activities. This includes matters pertaining to consumption and business activities that must be in line with the Syariah or the path that follows Islamic teaching. The recent emergence of Halal markets, also presents new opportunities for businesses with enormous potential of global market value for trade in Halal food and non-food products estimated at USD2.1 trillion annually, thus creating major interest both in Muslim and non-Muslim countries. According to Vohra, Bhalla and Chowdhury (2009), research has also shown that the Halal food market is expected to be worth about $\$ 580$ billion annually in 2007 . Undoubtedly, Halal markets present a vast opportunity for marketers both in Western and Islamic countries. This has forced businesses to observe and adapt to the changing environment where Halalness or Syariah compliance are of paramount importance to Muslim customers. As the global marketplace has transformed into a more sophisticated and demanding, business by any means necessary forced to formulate their business and marketing strategies that cater with their target market. The emergence of Muslim worldwide posed a greater need to understand to advance knowledge and understanding these customers.

Moreover, Daud et al., (2011) pointed out that Halal certification is a new concept in marketing as well as being a quality benchmark for the producer. It has become a vital marketing tool in promoting a product since it is not just representing quality but commitments towards religious commandments as well, at least for Muslims. In the Muslim market, businesses are expected to operate in compliance with Syariah or Islamic principles, especially in conducting their marketing strategy. Thus, it is necessary for businesses to develop appropriate marketing strategies for this kind of industry. In fact, Abdullah and Ahmad (2010) called for many viable Islamic guidelines for business, specifically in conducting marketing mix activities. This study specifically highlighted the need to develop promotional activities that are in line with Islamic principles. Subsequently, another study was carried out by Ahmad and Santhapparaj (2012) found out similar vein, calling for more studies to be carried out on marketing from an Islamic perspective especially on pricing strategy.

However to what extent this marketing knowledge able to accommodate such opportunity to market Halal product in the industry remain questionable. Alserhan and Alserhan (2012) 
revealed that, recent discovery of Muslims as a significant customer group lead to another startling fact, which is scarcity of literatures concerning these customers. Muslim consumers and businesses remained invisible, and a lack of academic and managerial interest in researching them persisted for a long time. Thus, it calls for more study to further equip these businesses to develop their marketing strategies especially marketing mix in parallel with Islamic principles.

\section{ISSUES IN ISLAMIC MARKETING}

\subsection{Islamic Marketing Mix}

A critical perspective on Islamic marketing has been put forward by Jafari (2012) in which author suggested production of knowledge and the improvement of current practice or Islamic marketing and business in general require reflexivity and self critique. Author constructive viewpoints shared a common ground with the primary aims of this paper. Several issues regarding Islamic marketing must be view from critical and empirical perspective. Currently works on Islamic marketing especially on Islamic marketing mix have been only "determining prescriptive religious practices and guidelines derived from holy texts, which are related to marketing" as suggested by Wilson (2012). In academia, there were quite a number of works in understanding Islamic approach in marketing, most of these literatures specifically scrutinized on the marketing mix such as by Wahab (1987), Gahein (1986), Haniff (1994), Sula and Kartajaya (2006), Arham (2010), Nadeem (2012), Abdullah (2008), Abdullah and Ahmad (2010), Damirchi and Shafai (2011), Ishak and Abdullah (2012), Abuznaid (2012). These literatures are useful in providing prescriptive religious practices and guidelines derived from to aforementioned Islamic teaching. These studies provided prescriptive religious practices and guidelines derived from Islamic teachings.

There were also previous literatures focused on conceptual study on Islamic marketing mix namely Arham (2010), Damirchi and Shafai (2011), Nadeem (2012), Ishak and Abdullah (2012), Abuznaid (2012) and some publications that were written as to give insight pertaining marketing by using Al Quran and As Sunnah such as Hanif (1994); Sula and Kartajaya (2006), Abdullah (2008) Sulaiman and Zakaria (2010) Gunara and Sudibyo, (2011) which are in need for empirical proves. These studies are in need of cogent ideas and empirical validation. Indeed, empirical study on this particular subject is limited, since only Abdullah and Ahmad (2010) and Ahmad and Santhapparaj (2012) have applied empirical methods to this subject while others still remain conceptual in nature. In fact, it has been suggested by Ismaeel and Blaim (2012) that more empirical studies are needed to further investigate especially Islamic business ethics application and Halal business practices, which are closely related to Islamic marketing. This paper acknowledges the necessity for more empirical studies thus taking issue to the next step in providing empirical evidence on critical factors in Islamic marketing mix using factorial analyses.

In addition, there are several standpoints regarding Islamic marketing mix which can be seen from the work by Al Buraey (1993), Gahein (1986) Anwar and Saeed (1996) and Wahab (1987). Nevertheless, to what extent Islamic perspective similar or differ with the existing conventional paradigm in practices still calling for much study to be carried out. Other than that, 
Tournois and Aoun (2012) stressed that the type of marketing or market orientation strategy to be adopted for engaging in Muslim majority markets remains subject to multiple standpoints. This has been popular subjects and research themes that given rise how the marketing strategies should be designed within existing framework or within Islamic marketing framework. Thus, providing new set of marketing framework within the margin of Islamic teaching is critical. This is due to the fact that, Arham (2010) claimed that it is imperative for Islamic marketing to screen any relevant theory of conventional marketing as to uniquely position itself in the body area of marketing. Despite the distinctive characteristics proposed by several authors such as Arham (2010), Alserhan (2011), Hanafy and Sallam (1988). Islamic marketing mix has not been clearly and empirically proposed in the form of 'hands on' framework that is feasible to be applied by businesses.

Besides that, recent emergence of Halal market also triggered more studies are needed on the subject beyond Halal product attributes such as Halal certification. A study by Zakaria and A. Talib (2010) has highlighted the importance of developing much comprehensive marketing guidelines beyond product development and production alone. Ideally Islam will observes and guide business conducts, in every aspects, As coined by A.T Kearney, businesses that comply with Syariah applied to the entire value chain, starting from the R \& D and design, sourcing, production, logistics to sales and marketing and it also includes Human resources and finance. Although, Halal certification has been seen as an effective marketing tool for the business (Shafie and Othman, 2006; Lada, Tanakinjal and Amin, 2009). Nevertheless, authors have urged more studies on the subject by highlighting the strong opportunity of Halal market and tailoring marketing strategies towards unique Muslim customer's needs. Ismaeel and Blaim (2012) argued that whether Muslim customer demand for just responsible Halal product or responsible Halal business beyond a product that certified as Halal just considering the product attributes.

Thus call for much wider multilevel Halal certification to the extent of overall business practices. This approach appears to be problematic in some ways, since reductionism in confining marketing within these inflexible margins, for instance Halal and Haram (Jafari, 2012), will definitely be destructive due to oversimplification, not to mention the complexity of determining marketing activities that are in line with Islamic teaching. According to Jafari (2012), Islam is resource rather than tools, thus author's concern over reductionist approach in Islamic marketing is of paramount importance. Concern over these narrow and static tenets of Halal and Haram as pointed out by Alserhan (2010) and Wilson and Liu (2010) shared by this paper therefore leads to more research on Islamic marketing beyond Halal or just Halal certification.

Although several studies had pointed out these guidelines and provided the theoretical foundation especially in carrying out marketing mix or 4Ps in line with Islamic teaching, nevertheless cogent constructs regarding such variables still have not empirically proven. In addition, customer point of view that has been the focal point of understanding marketing is indeed able to portray the right marketing mix variables that cater their needs and wants within the margin of Islamic teaching. Therefore, impetus to clarify critical factors in marketing mix is crucial to the practitioners and academician as to have suitable marketing mix targeted to 
Muslim customers. Thus imperative of highlighting the issue on the topic, specifically empirical study on the Islamic marketing mix worthwhile and present great benefit to the development of overall Islamic marketing and body of marketing. This study, although exploratory in nature, is aimed towards providing a viable Islamic marketing approach to be practically used by the businesses in implementing Islamic marketing mix strategies. Therefore highlighting the issue of the critical factors in Islamic marketing mix and developing new frameworks in conducting such strategies using both qualitative and quantitative research methods are indeed worthwhile and present great benefit to the development of the body of Islamic marketing and warrants this study to be carried out.

\section{METHODOLOGY}

The main purpose of this paper was twofold. Firstly it was designed to empirically identify critical factors in marketing mix in line with Islamic principles. Secondly, it assessed the order of importance of these factors. The process of developing the survey instrument was carried out in line with (Churchill, 1979) and adopted from Abdullah et al (2011) as shown in Figure 1.0. The questionnaire consisted of 3 major sections; Section A contained questions regarding demographic profile of the respondents. Section B contained 29 items randomly presented statements on Islamic marketing mix which has been developed using combination of content analysis using in depth literature review and survey form to illicit initial items and further confirmed by draft questionnaire and pilot test. Whilst for section $\mathrm{C}$ it contained questions pertaining customer satisfaction and loyalty.

Table 1: Distribution of the questionnaire

\begin{tabular}{lccc}
\hline \multicolumn{1}{c}{ Geographical areas } & $\begin{array}{c}\text { Distributed } \\
\text { Questionnaire }\end{array}$ & $\begin{array}{c}\text { Returned } \\
\text { Questionnaire }\end{array}$ & $\begin{array}{c}\text { Usable Questionnaire } \\
\text { (71.4\% response rate) }\end{array}$ \\
\hline Kuching Waterfront & 70 & 65 & 50 \\
Jalan India & 70 & 56 & 55 \\
Satok & 70 & 70 & 68 \\
Matang & 70 & 53 & 50 \\
Kubah Ria & 70 & 49 & 48 \\
Tabuan Jaya & 70 & 60 & 57 \\
Batu Kawa & 70 & 45 & 40 \\
Desa Ilmu, & 70 & 70 & 70 \\
Muara Tuang & 70 & 40 & 32 \\
Samarinda & 70 & 33 & 32 \\
Total & $\mathbf{7 0 0}$ & $\mathbf{5 4 1}$ & $\mathbf{5 0 2}$ \\
\hline
\end{tabular}

A total of 700 questionnaires were distributed by 10 enumerators in 10 selected parts of the two divisions (Stratified based on their geographical locations) specifically aimed at Muslim customers, resulting in 502 corrected and completed questionnaires obtained, yielding a response rate of $71.43 \%$ as shown in Table 1.0. The high response rate was due to the "personal contact' approach as suggested by Sureshchandar, Rajendran and Anantharaman, (2002). 
The number of usable sample of 502 is more than sample size of 384 which can represent a population size of more than half a million Muslim customers. According to State Planning Unit, Chief Minister Department, the population of Kuching was estimated around 600,000 in 2010 and Samarahan alone was estimated around 54, 700 in 2010 (Sarwak State Planning Unit, 2010). This sampling was representatively adequate and in parallel with the generalized scientific guidelines for sample size decisions as proposed by Krejcie and Morgan (1970). Data had been collected from customers of commercial centres in Kuching and Samarahan that have high populations of Muslim patrons.

Figure 1: Steps of Identifying Critical Factors in Islamic Marketing Mix and their Relationships with Customer Satisfaction

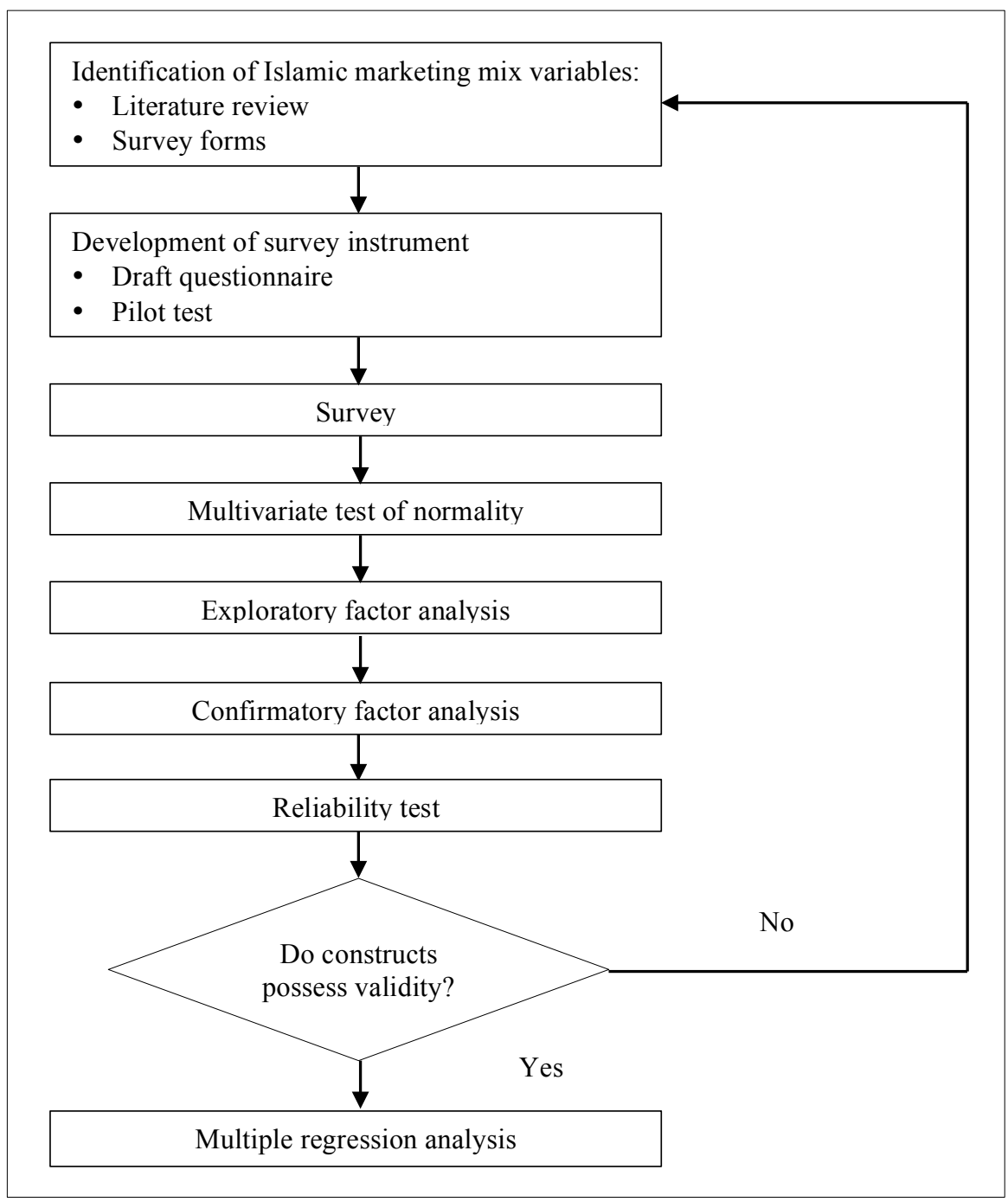




\subsection{Exploratory Factor Analysis}

Exploratory factor analysis was carried out in line with the best practices in Exploratory Factor Analysis, EFA suggested by Worthington and Whittaker (2006). Firstly, as to ensure adequate sampling for multivariate statistical analyses, according to Hair, sample size of $(\mathrm{N}=502)$ considered as $(\mathrm{N}=500)$ is good (Hair et al, 1995). Secondly, factorability of the data was also examined via significant of Bartlett test of sphericity and measuring the sampling adequacy using Kaiser-Meyer-Olkin (KMO). Both test were resulted in good outcome, with Bartlett test of sphericity was significant at $\mathrm{p}<0.00, \chi^{2}(, \mathrm{~N}=502)$ and further supported by KMO with the value of 0.927 was above the adequate sampling value of 0.6 as recommended by previous study. Structure of factor was further investigated by subjecting 29 items from section B of the questionnaire using factorial analysis. Maximum likelihood procedure was utilized together with varimax rotation in this stage. As suggested by Hair based on the range of aforementioned sample size in this study, $(\mathrm{N}=502)$ it was considerably acceptable to include a variable in a factor that has value of factor loading \pm 0.50 . Other than that, Tabachnick and Fidell (1989) suggest that all factors whose eigenvalues greater than 1.0 were retained in the factor solution. This was in line with Kaiser Criterion (retaining factors whose with eigenvalues greater than one) as supported by several works that argued this was the most appropriate in factor retention (Ford, McCallum and Tait, 2006).

\section{2. $\quad$ Scree Plot and Parallel Analysis}

The scree plot analysis and parallel analysis are another alternative criterion on how many factors to be retained. This test examined the pattern of eigenvalues for its breaks or discontinuity, which determine the cutoff point for the pattern. This cutoff point will determine number of optimum factors that can be extracted. Factor five was retained since parallel analysis shown it was only slightly under the intersection between factor analyses and was qualified for Kaiser Criterion and scree plot. On the other hand, factor six was dropped since it has insufficient item or factor loading per factor (at least three), although has common conceptual meaning, however it has been explained by other factor (Suhr, 2006). Five factors were retained and can be described as the following:

Factor 1: Commitment- This factor emphasizes on instilling assurance in business dealings via trustworthy marketing activities.

Factor 2: Characteristic- This factor describes the distinctive character of Islamic marketing. This uniqueness can be in terms of product design, specification and promotion that shall be reflecting and in line with Islamic values and characteristics.

Factor 3: Conformity- This factor scrutinizes on compliance in terms of process involved in creating and delivering the product and services involved in marketing Islamic product.

Factor 4: Conscience - This factor mainly relates to ethical dimensions of Islamic marketing. It mixed up combination of marketing mix that stressed on true sense of promoting and clarity in pricing a product in parallel with Islamic value.

Factor 5: Customer Centric - This factor describes an approach towards the customers, this combination mainly deals with basic marketing concept 


\subsection{Confirmatory Factor Analysis}

Confirmatory factor analysis was carried out by using lisrel framework (Joreskog and Sorbom, 1978). Since, this statistical approach useful to purify the measure via several tests, for instance unidimensionality, validity and reliability of the measurement instrument (Steenkamp and Trijp, 1991). Based on LISREL 9.1 Scientific Software International, a five- dimension measurement model was developed for each of the constructs within parametersestimated using aforementioned software. Based on the Figure 2.0, lisrel was used as to further confirm the five factors from EFA namely Commitment, Character, Conformity, Conscience and Customer centric as to find out whether there were good fit as a model. Findings shown that the model fit reasonable well using multivariate goodness-of-fit indices as shown in Table 2.0 which is in line with a set of rules of thumb has been adopted as recommended by Schermelleh-Engel, Moosbrugger and Müller (2003).

Table 2: Unidimensionality for Five Critical Factors in Islamic Marketing Mix

\begin{tabular}{lccc}
\hline \multicolumn{1}{c}{ Model evaluation } & Fit Indices & Range of Indices & Fit measure \\
\hline Chi-Square $\left(\chi^{2}\right)(p=0.00)$ & & & \\
Degree of freedom $(d f)=220$ & 623.694 & $\chi^{2} / d f=0.283$ & Good fit \\
Goodness-of-fit index $(\mathrm{GFI})$ & 0.903 & $0.90 \leq \mathrm{GFI} \leq 0.95$ & Acceptable fit \\
Adjusted Goodness-of-fit index (AGFI) & 0.879 & $0.85 \leq \mathrm{AGFI} \leq 0.90$ & Acceptable fit \\
Comparative Fit Index (CFI) & 0.969 & $0.95 \leq \mathrm{CFI} \leq 0.97$ & Acceptable fit \\
Non-normed fit index (NNFI) & 0.965 & $0.95 \leq \mathrm{NNFI} \leq 0.97$ & Acceptable fit \\
Incremental fit index (IFI) & 0.969 & $0.95 \leq \mathrm{IFI} \leq 1.00$ & Good fit \\
Root mean squared error of & & & \\
approximation (RMSEA) & 0.060 & $0.05 \leq \mathrm{RMSEA} \leq 0.08$ & Acceptable fit \\
\hline
\end{tabular}

Figure 2: Path Diagram of the Five Critical Factors in Islamic Marketing Mix

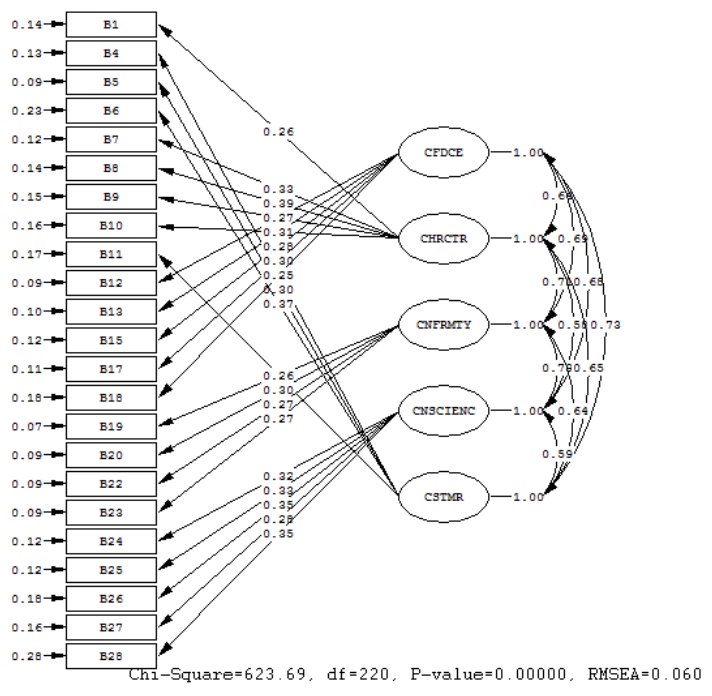




\subsection{Reliability Test}

In this case, internal consistency was assessed via Cronbach coefficient alpha suggested by Cronbach (1951). Internal consistency estimates of reliability was computed and five factor affecting Islamic marketing indicated that all of these factors were internally consistent with alpha value of more than 0.70 based on cutoff point suggested by Nunnally (1978). The alpha values are as follow: commitment $(0.770)$, character $(0.810)$, conformity $(0.775)$, conscience (0.752) and customer centric (0.738).

\subsection{Validity Test}

Several validity tests were used in this paper for the purpose of assessing validity of the measurement, namely face validity, content validity, convergent validity, discriminant validity and criterion-related validity. In this paper, face validity was assessed by qualitatively operationalized construct as to present unambiguous meaning of the subject being studied. Whereas, content validity emphasized on the relevancy of the content domains exist in the literature against the constructs of measurement. In depth search of relevant underpinning constructs of the theory being studied and ought to be measured shall qualified for such validity. In this paper, questionnaire was developed via in depth review of relevant literature and the construct has clear meaning to the respondents which clearly portrayed the subject to be measured. In this paper, the questionnaire was developed via in depth reviews of relevant literature on Islamic marketing mix (Wahab, 1987; Gahein, 1986; Haniff, 1994; Sula and Kartajaya, 2006; Arham, 2010; Nadeem, 2010; Abdullah, 2008; Abdullah and Ahmad, 2010; Damirchi and Shafai, 2011; Ishak and Abdullah, 2012; Pitchay, 2012; Abuznaid, 2012) and the construct has clear meaning to the respondents who clearly portrayed the subject to be measured as suggested by Bohrnstedt 1983; Kaplan and Sacuzzo, 1993).

Churchill suggests that convergent and discriminate validity should be assessed in investigating construct validity. The correlations coefficient among the five factors affecting Islamic marketing mix values range from 0.447 to 0.612 . Convergent validity can be portrayed by strong correlation between the constructs or components (Narver and Slater, 1990). Whilst, moderate positive relationship between the five constructs, indicating evidence of convergent validity and the absence of mutlicollinearity since correlation value is less than 0.8 (Kline, 1998). Therefore, convergent validity was achieved. Subsequently, discriminant validity can be determined by verifying those dimensions are differentiated or form the same factor. This can be assessed by subjecting the dimensions to a Chi-Square difference to examine the scale for discriminant validity. All the dimensions were assessed and found out to have statistically significant result at the $\mathrm{p}<0.01$ level. Therefore indicated distinctive constructs exited among all the five factors affecting Islamic marketing mix and the discriminant validity prevails. 
Table 3: Correlation of Five Critical Factors in Islamic Marketing with Customer Satisfaction

\begin{tabular}{cc}
\hline Factor & Correlation level \\
\hline Confidence & $0.336^{*}$ \\
Characteristic & $0.375^{*}$ \\
Conformity & $0.407^{*}$ \\
Conscience & $0.319^{*}$ \\
Customer Centric & $0.269^{*}$
\end{tabular}

Note: ${ }^{*}$ Correlation is significant at the 0.01 level (2-tailed).

Criterion validity concerns the correspondence of a measure with a criterion measure, a known and preferably standard measure of the same concept (Ping, 2004). In this paper, criterionrelated validity was established. Table 3.0 indicates that all the dimensions have a significant positive correlation with customer satisfaction. All correlation were significant at $\mathrm{p}=0.01$ level range ranged from 0.269 to 0.407 . Cohen (1988) suggests that those ranges can be considered as medium validity coefficient. Hence, criterion-related validity is established.

\subsection{Relative Importance of Five Critical Factors}

Multiple regression was used in this study to determine the overall effect of the five critical factors in Islamic marketing mix on customer satisfaction and to assess the relative importance of the individual dimensions. However, the presence of high correlations of 0.90 and above between independent variables may influence regression results and interpretations (Tabachnick and Fidell, 1996; Kline 1998). Analysis on multicolinearity also observed VIF values were ranged from 1.694 to 2.029 indicated that the absence of harmful multicolineraity. Linear combination of the five dimensions related to customer satisfaction, with $R^{2}=0.205$, adjusted $R^{2}=0.197, \mathrm{~F}(5,496)=25.641, \mathrm{p}=0.01$. The sample multiple correlation coefficient was 0.205 , indicating that approximately only $20.5 \%$ of the variance of customer satisfaction level in the sample can be accounted for by the linear combination of the five. It yielded only three factors contributing significantly towards explaining the variance in the overall customer satisfaction level. "Conformity" is found to be the most important factors affecting Islamic marketing mix, secondly "Character", thirdly "Commitment", followed by "Conscience" and "Customer" were found to be not significant to customer satisfaction $(\mathrm{p}<0.05)$.

\section{CONCLUSION AND RECOMMENDATION}

Primary contribution of this paper will help businesses in developing their marketing mix in line with Islamic principles and to be sensitive to Muslim customer. Findings suggest that Muslim customers consider five factors that are critical in conducting Islamic marketing mix in line with Islamic principles. These five factors derived from 23 items instrument on Islamic marketing mix that have been developed and empirically tested via factorial analyses. This will help businesses to conduct their marketing mix in line with Islamic principles when marketing a product to the Muslim customers. In conducting Islamic marketing mix five critical factors 
must be considered by the business namely: Commitment, Character, Conformity, Conscience and Customer centric. These factors found out to be moderately correlated with customer satisfaction. Multiple regression further indicated that Conformity, Character and Commitment significantly explain the variance of customer satisfaction. Therefore, this study proposed 5 strategies that are aimed toward implementing Islamically marketing activities based on these critical factors to be adopted by businesses.

\subsection{Consistently Conforming to Syariah}

It is prevalent that today, the emergence of certain standards that place emphasis on quality has attracted huge attention from many stakeholders. In the Halal industry this depicts commitment to quality in the light of Syariah guidelines and undeniably has become a major marketing tool in the current business environment. Due to this changing environment and to attract Muslim customers, ensuring the product and service can be consumed or used by the customers in line with Syariah is indeed crucial. Firstly, the production process must be pure from the beginning to the end; in this case it must stringently observe Syariah guidelines. Ensuring the process is in line with Syariah is even more important since this process will determine if the product can be consumed by the end user. As to monitor such process, it is vital to have a system that observes critical aspects of the process in parallel with Syariah guidelines. Perhaps it needs third party that has the authority to monitor such compliances. The business must be constantly checked for its ability to maintain stringent quality control on the production process, from procurement of raw materials, the use of proper machinery, to the use of proper packaging material, all of these must adhere to quality control principles. Thus, once this authentic Halal certification is acquired, the business must strive to maintain such status for their products, ensuring that phases of the production process, raw materials, equipment, tools and machinery are free from doubtful elements.

Furthermore, a business must hygienically handle their distribution in congruence with Syariah rules and regulations, for instance separation between Halal and non-Halal material and products to avoid doubtful practices in distributing the product. The business should take into consideration the distribution of the product due to cross-contamination that may occur, or a product may make contact with Haram (non-permissible) elements during the product handling. A business must ensure that distribution has proper documentation, proper carriage or transportation, prudent material handling and safe packaging suitable for distributing the products, and lastly a suitable warehouse. Monitoring such aforementioned aspects needs to be taken seriously. Proper documentation in terms of tagging, proper arrangement of delivery and separation between non-permissible products must be highlighted. In terms of carriage or transportation used, these carriers must be suitable to the nature of the product, for instance frozen food products must have trucks that have cold storage to ensure quality. This is to ensure safety and that the condition of the product still meets the status of permissible. Warehouse or storage used must be hygienically maintained, since, cross-contamination can happen in any of this distribution process. This is to avoid faults or errors that compromise the status of the product.

In some cases, businesses are to hire or outsource the distribution of the product as part of their business strategy. In this case, finding certified distributors is vital to select a supplier 
that provides permissible input or raw materials. All the aspects of distribution as delineated earlier should be taken into consideration. Thus it is best to select certified distributors that have the aforementioned criteria that comply with Syariah. To commit to such conformity to Syariah, the business must make sure the distributor has applied for such standards from recognized bodies such as Jabatan Kemajuan Islam Malaysia, JAKIM to ensure authenticity of such certification, since these standards cover 5 key areas, namely management, receiving, processing and handling, storage and delivery.

\section{2. $\quad$ Exhibiting Distinctive Characteristic}

Intense competition has brought innovative ideas to be different from others. Differentiation is seen as the best remedy to survive in such environment. In this case, the distinctive characteristic of the Islamic approach in marketing can be best represented by staying on the path illuminated by Syariah. The distinctive characteristic of an Islamically rooted business can be shown by offering only lawful or permissible products and services in line with Syariah. The reason behind the emphasis on permissibility is the universal set of principles applied to all humans, not just for the Muslims. Permissibility of products from Islamic point of view is to safeguard the welfare of the customer and ensuring quality that is universal in nature. It is also an opportunity for a business to distance itself from conventional paradigm that removes religious views on certain critical marketing decisions on product offered to the target market. Therefore, a business that adopts an Islamic approach in marketing a product must differentiate their product by having such permissibility or certification that represents compliance to Syariah and quality as well.

One of the most important aspects in offering a product is product design that meets customer needs and wants. In terms of design, creative and attractive design must be done in a way that it reflects Islamic characteristics and able to attract potential buyers. Although such an approach is open to cultural interpretation, but the underpinning values and characteristic of Islam must be emphasized as to stand out from the rest. One of the ways to reflect Islamic characteristics onto the product is by adding distinctive features which are suitable for Muslims. This is by emphasizing products that follow the Sunnah of the Prophet Muhammad S.A.W in terms of food, clothing, that are aimed at Muslim consumers. A product must be determined in such a way that it is fair to be offered in the market. For a tangible product, specifications of such products and services should parallel Islamic values as well, such as clarity in offering, correct and appropriate measurement accurate labeling clearly, and packaging used should be made from permissible, safe and durable materials and etc.

It is crucial to design and develop product specification and show the accurate measure or amount of the product. Other than that, communication in marketing should emphasize Islamic values in promoting products to the market. As to come up with its own distinct characteristic, Islamic values should be embedded in communicating the product to potential customers. Wisdom or Hikmah must be at the heart of communication in Islamic marketing. A business should be able to construct creative message while promoting moderation in consuming and buying a product. Extravagant spending behaviour should not be encouraged by a business to spruce up the sales. Businesses must find ways to communicate careful spending and affordable products and serve the needs of consumers within the range of their incomes. Besides that, 
communication should emphasize only Halal products and promote elements of brotherhood, and highlight good values to attract their customers.

Lastly, as to ensure businesses have a distinctive characteristic products and services should be pure from the beginning to the end, and this should be maintained and across business alliances, Islamic marketing should extend to having a good relationship with the suppliers based on the spirit of brotherhood in Islam including to ensure such products meet the standards from the farm to the end product. Therefore, to have a distinct characteristic, one must consider suppliers as the backbone of the business. Thus, as the business complies with Syariah, these suppliers must also comply with Syariah to ensure all aspects of the business are in line with Islamic teachings. As suggested by Tieman in the case of Halal certified companies or business, it is crucial to go beyond the production and ingredients and to extend Halal to the entire supply chain to ensure it meets the requirements of the target market, especially Muslims. This is the distinctive characteristic of a business that goes to the source of the product ensuring permissibility and responsibility to give confidence and to avoid doubtful thoughts in customers' minds.

\subsection{Instilling Assurance}

Customer confidence and trust is definitely the main reason for a business to survive in the long term. This has been the main priority practiced by Prophet Muhammad S.A.W, as mentioned by authors such as Trim (n.d) in instilling assurance via credentials and honest business conduct. Transactions that might involve individuals or a group of individuals should have obligations towards others, especially for Muslims. A Muslim is a brother to the other Muslims, therefore injustice conducted in business activities is to be avoided so as to build up trust and safeguarding long lasting relationships (Silaturahim). A business must translate their 'Commitment' in carrying out their Islamic marketing mix, which can be delineated by having (1) Clear marketing goals, (2) Clear informative offerings, (3) Truthful communication, (4) Fulfillment of promises and (5) Highly ethical personnel.

In order to portray such commitment, a business must have a clear goal which is aimed at realization of justice in business transactions or dealings. Marketing goals must create values and elevate the standard of living of the people through commercial pursuits and avoidance of profit maximization alone which encourages selfish extravagant behaviour. Thus, it must be in line with Islamic teachings which emphasize 'fair play' or 'just dealing' in translating the commitment as one of critical factors perceived in the Islamic marketing mix by the customer. Besides that, ambiguity in delivering information about the offering may lead to misinterpretation, misjudgement and can be seen as a way to deceive customers, therefore businesses must present enough information to give a clear picture of the offering. The implementation of such a commitment to convey clear information about the product and services must be monitored. For instance, a business must have a unit that controls marketing information which is to be disseminated to their customers. Specifically in monitoring information about the product and services so as to avoid confusion and misinforming customers. In communicating such offerings, as to practice a truthful means of communication, a business must disclose any known faults of the product or service (as suggested by Saeed et al., 2001). 
Other than that, as the business may be prone to exaggerate their claims about the product and service to ensure it performs perfectly as expected, over-promising of such promotional claims should be avoided. This is in parallel to Islamic teachings in Al Quran, in Surah Al Maidah, Verse 1, (Al Quran, 5:1) which commanded Muslims to fulfill their promises or Aqad. This has been further emphasized in another verse, (Al Quran, 17:34) where fulfillments of such promises were emphasized since it will have the consequences or responsibility. These promises indeed are commitments that have great implications both in the short and the long term. A product must be carefully assessed in terms of its performance and businesses must have reasonable promises that ensure the product will perform for certain periods of time, and these guarantees and warranties will project their commitment in delivering these promises to the customer. Businesses must continuously show highly ethical conduct or Akhlak as a first impression of such commitment towards implementing Islamically rooted marketing activities. The personnel in a business are the ambassadors of that business, since their personality and character represent the business. Therefore, planning and continuously giving appropriate training that will develop their skills and understanding towards building a good image for the business by professionally acting on behalf of the business. Islamic values must be embedded in building their character and personality, and this training must not only focus on technical operations of the business but also these personnel must be spiritually in line with their technical knowledge and development.

\subsection{Embedding Morality and Conscience}

Ethical issues with regard to marketing are not new to the field, both in academic research and practice. Customer perceptions towards marketing activities often relate unethical conduct being carried out by businesses. There are many critics of marketing practices in the literature as well as in the mass media. Thus marketing is needs of sound strategies in implementing its activities. An ethically sound strategy that is in line with Islamic principles must focus on morality and conscience. It must carefully guide the customer expectation in positioning certain products in the mind of customers. A business should manage customer expectations by carefully communicating a reasonable picture of the performance of their product. This is to give a clear assumption of what to expect when consuming or buying these products. Most important of all is honesty in conveying the benefits and defects of their products to assure that products will satisfy the customer. Besides that unethical appeals such as sexual, emotional and false research must strictly be avoided by Islamic businesses. This can be monitored by having an internal committee that screens out elements of advertising that are not in line with Syariah. This Syariah observation committee should have the authority to screen inappropriate elements to be presented to the target audience. Elements of Islamic teachings must be embedded into the advertisements, for instance commandments in Al Quran, to give awareness to the target audience. It is vital to have such internal committees within the business to monitor the promotional activities, particularly in advertising.

Other than that, it is critical to have reasonable and ethical pricing for a product, since it is the most sensitive issue when offering a product to a target market. Although there is no absolute ruling suggesting how to charge customers for a certain product and service, prices should have moral or ethical justification guided by Islamic principles such as justice. As set by Prophet Muhammad S.A.W, price control must not be excessive, and price fixing is prohibited since it 
affects the market mechanism which is determined by the interaction of demand and supply. This market mechanism is seen as a natural law, thus the practices of Prophet Muhammad avoid such price controls but urge for moral reform by businesses to lower their prices. A business can set the price as long as injustice does not prevail in the market. Carrying out promotional activities that involve pricing strategies such as discounted pricing must be without elements of Tatfif which means a business should appropriately give discounted prices in line with the reasonable quality and quantity of the product. Price discounts must not be manipulated to boost up sales, instead they are to encourage prudent spending and affordable prices for certain customer segments. Likewise, the quantity of the product should not be reduced in line with the discounted price, where technically the notion of "discounted price" is not applicable. Since the price is said to be reduced, nevertheless quantity at the same is compromised. This unethical conduct should be avoided so as to follow Islamic guidelines, since the rationale of such avoidance is for a company to ensure justice is served regardless of the strategy used.

\subsection{Embracing a 'Customer Oriented'Approach.}

Existing literature and current practices have pointed out the importance of customer oriented businesses or marketing orientations. Emphasis behind such orientation is due to the fact customer is the heart of marketing success. Nevertheless, it must be emphasized that this fulfillment should be in line with Islamic teachings such as permissibility or compliance toward Islamic law or Syariah. Although, undeniably cultural differences do exist in these different Muslim customer segments and need to be taken into consideration. Besides that, majority of the customers are looking for high quality product that is durable and able to perform what has been claimed by the marketers through their promotional activities or the product information in the product. In this case, offering high quality product is the priority for the marketers as to ensure the customers are satisfied with their product. In fact, it has been practiced by Prophet Muhammad S.A.W that no low quality product should be offered along with good quality product as to deceive customers. It is to project the right expectation of the customers that a high quality product will lead to customer satisfaction.

Branding is one of the main strategies that have been the focal point of marketing success in the $21^{\text {st }}$ century. Building a sense of confidence, trust and belongingness towards a certain brand is the key to long lasting relationship between the business and the customers. Marketers or businesses can applied such strategy and build up their brand by projecting a good character, ethical conducts in business, being truthful and honest as a person. This needs to be spread all across the organization, not only to the marketing department that responsible to build and project a good attribute of branding for the company but to be embedded in all member of the business organization. A true sense of branding strategy derived from a solid attributes of personality for a long lasting relationships. Thus, branding through word, trademark, and other forms of branding tool must be holistically developed considering good character of people that are associated with the businesses.

Distribution of products should be available and easy to find on the shelf together with the help of salesperson. This is no different in practicing Islamic marketing mix; Muslim consumers desire the same thing as consumer in general. Businesses must emphasize on offering convenience to the customers in delivering their product to the right customer, at the 
right amount and the right quality. This is to avoid customer to feel deceived and to cause the inconvenience, such as offering product targeted to wrong target market, availability of the right product to the right customers is compromised and scarcity of needed product in a certain area of Muslim populated area. As for example, in a largely Muslims populated area which are in need of Halal products, should have enough desired product such as Halal food, consumer goods and etc as to avoid them to consumed doubtful or even worse Haram product which are against Islamic teaching. In fact, having distribution that offers convenience to the Muslim customers is critical to safeguard Syariah rules and regulation and to serve Muslims customers in line with Islamic teaching.

\section{REFERENCES}

Abdullah, F., Suhaimi, R., Saban, G., \& Hamali, J. (2011). Bank service quality (BSQ) index: an indicator of service performance. International Journal of Quality \& Reliability Management, 28(5), 542-555.

Abdullah, K. (2008). Marketing mix from an Islamic perspective: A guide for marketing courses. Selangor: Pearson Prentice-Hall

Abdullah, K., \& Ahmad, M. I. (2010). Compliance to Islamic marketing practices among businesses in Malaysia. Journal of Islamic Marketing, 1(3), 286-297.

Abuznaid, S. (2012). Islamic Marketing: Addressing the Muslim Market. An-Najah University Journal for Research, 26(6), 1473-1503.

Ahmad, M. I., \& Santhapparaj, A. (2012) Perspective of Muslim consumer on Islamic pricing practice among businesses in Malaysia. In O. M. Zain (Eds.), Readings in Marketing: An Islamic Perspective (pp. 208-223). Malaysia: IIM Press.

Al Buraey, M. A. (1993). Miskeen ad darmi: first marketing expert in Islam. Al-Ikhtisad, 245(26), 42-43.

Alserhan, B. A. (2010). On Islamic branding: brands as good deeds. Journal of Islamic Marketing, 1(2), 101-106.

Alserhan, B. A. (2011). The Principles of Islamic Marketing. London, UK: Gower Publishing Company.

Alserhan, B., \& Alserhan, Z. (2012). Researching Muslim consumers: do they represent the fourth-billion consumer segment? Journal of Islamic Marketing, 3(2), 2-2.

Anwar, M., \& Saeed, M. (1996). Promotional Tools of Marketing: An Islamic Perspective. Intellectual Discourse, 4(1-2), 15-30. 
Arham, M. (2010). Islamic perspectives on marketing. Journal of Islamic Marketing, 1(2), 149-164.

Bohrnstedt, G. (1983). Measurement. In P. Rossi, J. Wright \& A. Anderson (Eds.), Handbook of Survey Research, (pp. 98). San Diego: Academic Press.

Churchill, G. A. (1979). A paradigm for developing better measures of marketing constructs. Journal of Marketing Research, 16(1), 64-73.

Cohen, J. (1988). Statistical power analysis for the behavioral sciences (2nd ed.). Hillsdale, NJ: Lawrence Erlbaum Associates

Cronbach, L. J. (1951). Coefficient alpha and the internal structure of tests. Psychometrika, $16(3), 297-334$.

Damirchi, G. V., \& Shafai, J. (2011). A guideline to Islamic marketing mix. Interdisciplinary Journal of Contemporary Research in Business, 3(3), 1339-1347.

Daud, S., Din, R. C., Bakar, S., Kadir, M. R., \& Sapuan, N. M. (2011). Implementation of MS1500: 2009: A Gap Analysis. Communications of the IBIMA, 1-11.

Ford, J. K., MacCallum, R. C., \& Tait, M. (2006). The application of exploratory factor analysis in applied psychology: A critical review and analysis. Personnel Psychology, $39(2), 291-314$

Gahein, M. M. (1986) Marketing Strategies of Small Companies with particular reference to the textile industry in Egypt as an Islamic Developing Country. (Unpublished Doctoral Dissertation) University of Strathclyde, Scotland, UK.

Gunara, T., \& Sudibyo, U. (2011). Marketing cara Rasulullah S.A.W. Kuala Lumpur: Synergy Media.

Hair, J. F., Anderson, R. E., Tatham, R. L., \& Black, W. C. (1995). Multivariate data analysis with readings, $4^{\text {th }}$ Edition. Upper Saddle River, New Jersey: Prentice-Hall International, Inc.

Hanafy, A. A., \& Sallam, H. (1988). Business ethics: An Islamic perspective. Paper presented at the Seminar on Islamic Principles of Organizational Behavior, IIIT, Herndon, USA.

Haniff, M. S. (1994). Fundamentals of Islamic marketing handbook. Kelantan: Pustaka Aman Press

International Islamic University Malaysia. (2012). Retrieved December 19, 2011, from http:// www.lib.iium.edu.my/elmu-rm/mom2-documentresults.jspRMK-10 2010 
Ishak, M. S. B. H., \& Abdullah, O. C. (2012). Islamic Perspective on Marketing Mix. European Journal of Scientific Research, 77(2), 214-220.

Ismaeel, M., \& Blaim, K. (2012). Toward applied Islamic business ethics: responsible Halal business. Journal of Management Development, 31(10), 1090-1100.

Jafari, A. (2012). Islamic marketing: insights from a critical perspective. Journal of Islamic Marketing, 3(1), 22-34.

Joreskog, K. G., \& Sorbom, D. (1978). Analysis of Linear Structural Relationships by Method of Maximum Likelihood. Chicago, IL: National Educational Resources.

Kaplan, R. M., \& Sacuzzo, D. P. (1993). Psychological testing: principles, applications and issues, $3^{\text {rd }}$ Edition. Pacific Grove, CA: Brooks Cole.

Kline, R. (1998). Principles and practice of structural equation modeling. New York: Guilford Press

Krejcie, R. V., \& Morgan, D. W. (1970). Determining sample size for research activities. Educational and Psychological Measurement, 30, 607-610.

Lada, S., Tanakinjal, G. H., \& Amin, H. (2009). Predicting intention to choose halal products using theory of reasoned action. International Journal of Islamic and Middle Eastern Finance and Management, 2(1), 66-76.

Muqorobin, M. (2004). Landscape for the future Islamic Economics. Journal of Islamic Economics Forum for Indonesian Development, 3(3), 21-39

Nadeem, S. (February, 2012). Islamic Principles on Marketing. Unpublished paper presented at International Conference on Islamic Business and Finance, Islamabad, Pakistan.

Narver, J. C., \& Slater, S. F. (1990). The effect of a market orientation on business profitability. Journal of Marketing, 54(4), 20-35.

Nunnally, C. (1978). Psychometric theory, $2^{\text {nd }}$ Edition. New York: McGraw-Hill.

Pew Research Center. (2009, October). Mapping the global Muslim population: A report on the size and distribution of the world's Muslim population. Washington DC: The Pew forum on religion \& public life.

Ping, R. (2004). On assuring valid measures for theoretical models using survey data. Journal of Business Research, 57(2), 125-141

Pitchay, A. A. (2012). Marketing Mix From Islamic Marketing Perspective. Social Science Research Network. Retrieved April 24, 2012, from papers.ssrn.com/so13/papers. cfm?abstract_id=2017488 
Saeed, M., Ahmed, Z. U., \& Mukhtar, S. M. (2001). International marketing ethics from an Islamic perspective: a value maximization approach. Journal of Business Ethics, 32(2), 127-142.

Sandikci, Ö. (2011). Researching Islamic marketing: past and future perspectives. Journal of Islamic Marketing, 2(3), 246-258.

Sarawak State Planning Unit (2010). Sarawak Facts and Figures 2010. Sarawak, Malaysia: State Planning Unit, Chief Minister's Department.

Schermelleh-Engel, K., Moosbrugger, H., \& Müller, H. (2003). Evaluating the fit of structural equation models: Tests of significance and descriptive goodness-of-fit measures. Methods of psychological research online, 8(2), 23-74

Shafie, S., \& Othman, P. D. M. N.( Seotember, 2006). Halal Certification: an international marketing issues and challenges. Paper presented at IFSAM VIII World Congress, Berlin, Germany.

Steenkamp, J. B. E., \& Van Trijp, H. (1991). The use of LISREL in validating marketing constructs. International Journal of Research in Marketing, 8(4), 283-299.

Suhr, D. D. (2006). Exploratory or confirmatory factor analysis? Cary: SAS Institute, 1, $66-76$.

Sula, M. S., \& Kartajaya, H. (2006). Syariah Marketing. Bandung: Mizan publishing.

Sulaiman, M., \& Zakaria, A. (2010). Jejak Bisnes Rasul. Selangor, Malaysia: PTS Professional Publishing.

Sureshchandar, G. S., Rajendran, C., \& Anantharaman, R. N. (2002). The relationship between service quality and customer satisfaction-a factor specific. Journal of Services Marketing, 16 (4), 263-279.

Tabachnick, B., \& Fidell, L. S. (1989). Using multivariate statistics. Cambridge: Harper Collins College Publishers.

Temporal, P. (2011). Islamic Branding and Marketing: Creating a Global Islamic Business. London: Wiley

Tournois, L., \& Aoun, I. (2012). From traditional to Islamic marketing strategies: Conceptual issues and implications for an exploratory study in Lebanon. Education, Business and Society: Contemporary Middle Eastern Issues, 5(2), 134-140.

Vohra, M., Bhalla, G., \& Chowdhury, A. (2009). Understanding the Islamic consumer. Research and Society: Research World, 40-43. 
Wahab, M. A. (September 1987). Marketing Concept and Strategies An Islamic Approach. Unpublished paper presented at Economic Society, Seminar of Contemporary Business IIUM. Kuala Lumpur, Malaysia.

Wilson, J. (2012). The role of Islamic marketing researchers: scribes, oracles, trend spotters-or thought leaders? Setting the agenda. Journal of Islamic Marketing, 3(2), 104-107

Wilson, J. A., \& Liu, J. (2010). Shaping the halal into a brand? Journal of Islamic Marketing, 1(2), 107-123.

Worthington, R. L., \& Whittaker, T. A. (2006). Scale development research a content analysis and recommendations for best practices. The Counseling Psychologist, 34(6), 806-838.

Zakaria, N., \& Talib, A. N. A. (2010). Applying Islamic market-oriented cultural model to sensitize strategies towards global customer, competitors and environment. Journal of Islamic Marketing, 1(1), 51-62. 